\title{
THE IMPORTANCE OF ACQUIRING INTERCULTURAL COMMUNICATIVE COMPETENCE FOR PRESENT AND FUTURE TOURIST PROFESSIONALS IN MONTENEGRO
}

\author{
Gordana Mušura
}

DOI: https://doi.org/10.31410/ITEMA.2020.69

\begin{abstract}
The aim of this paper ${ }^{2}$ is to discuss and emphasize the importance of acquiring and developing intercultural communicative competence (hereinafter ICC) for tourist professionals in the context of strategic advantages of Montenegro as a tourist destination. Montenegro, as a multicultural, multiethnic and multi-confessional country with a very rich and ancient cultural heritage and preserved natural resources, strives for European integration and achieving international competitiveness in the field of tourism through the development of its strategic advantages. In order to achieve progress in tourism industry, it is necessary to apply an interdisciplinary approach, which includes a symbiosis of elements of culture and tradition with the need and demands of modern tourists who want to communicate with the domicile population, or at least with their hosts, as well as to feel comfortable and welcome at the destination they have chosen for their holiday. Therefore, communicative and affective segments must be added to this interdisciplinary approach which inevitably includes the acquisition of new skills in intercultural communication at the international level. Such communication enables the development of ICC through the inclusion of both linguistic and cultural elements of education in tourism and applying the intercultural approach in foreign language teaching. Furthermore, developing intercultural aspects in tourism should be seen as one of core advantages of smaller and still insufficiently affirmed tourist regions, such as Montenegro, especially in these disruptive circumstances of crisis caused by Covid-19 virus.
\end{abstract}

Keywords: Intercultural communication, Globalization, Intercultural approach in foreign language teaching, Intercultural speaker, Intercultural awareness and sensitivity, Long-life learning.

\section{INTRODUCTION}

$\mathrm{O}$ ur contemporary reality is characterized by globalization and interculturality. Migrations of the population and the permeation of their cultures and languages are becoming more and more emphasized, which has imposed the need to focus on the intercultural aspect, both in the school and work environment of people. Tourism, as a branch of economy that includes a large number of people, both tourists and tourist workers and residents of the receptive tourist area, is in direct connection with globalization processes characterized by intercultural contacts and human relations conditioned by their different national, linguistic, cultural, religious and identity differences. Therefore, it is extremely important that all the afore mentioned actors establish appropriate intercultural communication

\footnotetext{
Faculty of Business and Tourism, Akademija znanja, Budva, Montenegro

Some segments of the paper were taken, adapted and translated into English from the doctoral dissertation "Sticanje interkulturne komunikativne kompetencije u nastavi italijanskog jezika kao stranog u osnovnoj školi” (Mušura, 2019). (“Acquiring intercultural communicative competence in teaching and learning Italian as a foreign language at elementary school")
} 
that will lead to mutual respect and appreciation of cultural differences, tolerance and understanding of "otherness", which are the basic postulates of acquiring intercultural competence. This competence will enable them to overcome stereotypes and prejudices about other nations, especially in the sphere of cultural tourism. In order to achieve this, it is necessary to establish an intercultural approach in teaching in the school system, from the earliest age of children in the lower grades of primary school, through secondary school and higher education at the university, on the one hand, and, on the other hand, to continuously educate tourism workers in the direction of interculturalism, which is in line with the principles of the Council of Europe on long life learning.

\section{INTERCULTURAL COMMUNICATIVE COMPETENCE}

When communicative competence is combined with intercultural competence, intercultural communicative competence is created (hereinafter ICC), as Byram (1997), the creator of this concept, points out. Acquiring ICC means developing the ability to interact in complex cultural contexts among people who have more than one cultural identity and language. Accordingly, it is necessary to create an intercultural classroom that will be characterized by the transformation of identity, the student as an examiner and the process. When ICC becomes an integral part of the language classroom, students will experience how to use language, build relationships and mutual understanding with members of other cultures, re-examine their own beliefs, viewed through a different perspective, negotiate points of view that are different from theirs and discern into another culture. By incorporating certain activities to promote ICC in the curriculum, students will begin to see how their attitudes, knowledge, and language skills can influence their intercultural experiences (Moeller \& Nugent, 2014).

Byram (1997) sees the ICC as a complex system that develops as a result of different nonnative speaker experiences, such as formal education, practical work, and independent learning. Byram's model is popular among foreign language teachers and its components are recognized as general competencies that should accompany communicative competence. Corbett $(2010, \mathrm{p}$. 2) notes that the detailed specification of the ICC is still an evolving project, although it was Byram and his colleagues who achieved a great deal by working on this. In the Framework ${ }^{3}$, of which Byram is one of the authors, ICC is understood as a set of knowledge, skills and attitudes. Building on Byram's work, Corbett summarizes five basic aspects of the ICC, namely:

a) knowledge about oneself and others

b) to know how to relate to meaning and how to interpret it

c) developing critical awareness

d) to know how to reveal cultural information

e) to know how to relativize oneself and evaluate the attitudes and beliefs of others

\section{INTERCULTURAL SPEAKER IN INTERCULTURAL COMMUNICATION}

Intercultural learning and teaching have imposed some new challenges on previous models. Corbett (2010, p. 1) points out that they, above all, challenged the conventional goal of language education, which sought to acquire the language skills of the native speaker of the foreign language being taught. For many students, that was an unattainable goal, and as the author notes, many teachers claim that it is now an unnecessary goal, especially if we bear in

Common European Framework of Reference for Languages: Learning, Teaching, Assessment. Companion volume new descriptors. (2018). Council of Europe 
mind the fact that English is becoming a global and universal language of communication, i.e. a kind of lingua franca of the modern age, as it was once the Latin language in the Middle Ages. Therefore, it is more acceptable for most people to establish communication and achieve functional language use than to strive for the perfection of native speakers in the UK, the USA or Australia. Therefore, the intercultural speaker takes precedence in international communication over the native speaker of a language. Intercultural education has certainly contributed to this, when intercultural students, as Corbett further states (ibid.), use language to explore different cultures and to mediate in those situations where cultural misunderstandings occur. They do it in a sophisticated way, using their acquired knowledge of culture and developed skills in using the resources of the target language. They are also encouraged to include their personal qualities, such as empathy, openness and respect for others.

The intercultural speaker is the main actor in intercultural communication and therefore it is essential to analyze and observe the development of his intercultural competence, which is very important in modern intercultural and multilingual environments. Byram (1997) defines the term of intercultural speaker as a person who possesses knowledge of one or more cultures and social identities and someone who enjoys discovering and maintaining relationships with people from other cultural backgrounds, even though he is not formally educated for that purpose. It is a person, according to House (2007), who managed to develop his third way, which is among other cultures that are close to him. Such a person should be understood as independent both of his or her original culture and language and of the new culture and language he or she wishes to connect, mediate and harmonize between them. He or she creates something new and autonomous in between, something hybrid, which is the third way. Such a person is an active participant who organizes her or his discourse creatively and independently, offering deeper views and understanding.

The aim of modern foreign language teaching, as an integral part of education for tourism professionals, is no longer for students to master language skills and competencies, but also to acquire plurilingual and intercultural communicative competence that are an integral part of intercultural education. They imply activating all students 'potentials related to knowledge of foreign languages, regardless of the level and degree of knowledge, as well as all transversal knowledge from culture, to monitor students' personal development and their needs during language learning, so that progress in development their linguistic and intercultural abilities lead them to become primarily intercultural rather than native speakers of a foreign language.

\section{INTERCULTURAL COMMUNICATIVE COMPETENCE IN THE TOURISM IN MONTENEGRO}

This is exactly the profile of an intercultural speaker that all those involved in the tourism sector in Montenegro should strive for. Montenegro has a very diverse population that has lived together for centuries in harmony and mutual tolerance, resisting the dangers that lurked during numerous wars that took place in the long history of this country. In this way, its inhabitants have managed to preserve multicultural, multiethnic and multi-confessional harmony, which can be considered one of the important resources for the development of modern forms of tourism. In addition to this human resource, Montenegro abounds in very numerous and diverse cultural and historical monuments, some of which date back to ancient times. This cultural heritage attracts many tourists from different parts of the world and contributes to the development of cultural tourism. Tourists also like the natural beauties of this country, such as 
the beautiful sandy beaches of the Adriatic Sea in the south and the untouched beauty of the mountainous area in the north of the country.

However, this is not enough to meet the needs of the modern tourist who, in addition to an excellent offer of accommodation, gastronomy and entertainment, wants a more complete experience and a more comprehensive approach during his or her stay at a particular destination. Such a tourist wants to feel welcome, to talk to the domicile population, to get to know the peculiarities of the new destination and the way of life of its people. He or she wants to feel the affective side of his or her hosts, i.e. to recognize in their smile and facial expression true hospitality and satisfaction that they welcome him or her as a dear guest. Such a tourist also wants to spend his or her holiday in the belief that he or she will come to the same destination again because it was a nice and pleasant place which he or she will definitely recommend to the family members and friends. Therefore, it is necessary for tourism workers in Montenegro to be sensitized to this aspect of their work, which will include continuous education and training and an interdisciplinary approach. It means that the essential elements of culture and tradition need to be combined with various forms of communication skills and ability to develop cultural sensitivity in contacts with foreign tourists. Apart from being an important component of education for present and future successful tourism professionals, this should be a new form of intercultural dialogue between people in modern globalized world that requires mutual understanding and intercultural awareness and sensitivity. It also requires long life learning and constant training. Furthermore, developing intercultural aspects in tourism should be seen as one of core advantages of smaller and still insufficiently affirmed tourist regions, such as Montenegro, especially in these disruptive circumstances of crisis caused by Covid -19 virus.

\section{CONCLUSION}

The paper considers the importance of acquiring intercultural communicative competence for present and future tourist professionals in Montenegro. As a small country that strives for European standards and integration and sees its prosperity in the development of tourism as one of the main economic branches, Montenegro has to allow its tourism representatives to improve their intercultural communication. Such communication will enable the development of ICC through the inclusion of both linguistic and cultural elements of education in tourism and applying the intercultural approach in foreign language teaching. Both of these will contribute to a better future in the field of tourism.

\section{REFERENCES}

Byram, M. (1997). Teaching and assessing intercultural communicative competence. Clevedon: Multilingual Matters

Corbett, J. (2010). Intercultural language activities. Cambridge: Cambridge University Press.

Moeller, A. J., Nugent, K. (2014). Building intercultural competence in the language classroom. Downloaded from: http://www.digitalcommons.unl.edu 